\title{
Genetics of Spondyloarthropathies and Inflammatory Bowel Disease: Searching for Common Susceptibility Factors
}

\author{
Debby Laukens* and Martine De Vos
}

\author{
Department of Gastroenterology, Ghent University Hospital, Gent, Belgium
}

\begin{abstract}
Ileocolonoscopic evidence for subclinical gut inflammation is found in a subpopulation of spondyloarthropathy (SpA) patients. The prevalence of microscopic intestinal lesions is even higher and can be classified as either an acute or a chronic type of inflammation. The latter condition is associated with an increased risk of developing overt inflammatory bowel disease (IBD), especially Crohn's disease (CD), over time. Evidence for genetic predisposition in both SpA and IBD is strong, and has resulted in the identification of several linked chromosomal loci and putative candidate genes. The regular co-existence of SpA and IBD within the same family suggests a common genetic component. Interestingly, comparison of genome-wide linkage and association data reveals thirteen disease-associated chromosomal regions that are shared between SpA and IBD. This should convince geneticists to examine genes within these regions as potential susceptibility genes for the development of both SpA and IBD. Significant association of such shared genetic determinants was established for NOD2 (16q), the major histocompatibility complex I allele HLA-B27 (6p) and recently also the interleukin 23 receptor (1p). Transgenic animals in which tumor necrosis factor alpha or HLA-B27 is overexpressed suffer both joint and gut abnormalities resembling human SpA/CD pathology, providing additional evidence for a common genetic predisposition for the onset of joint and gut inflammation. In view of a hypothetical pathway leading to intestinal and articular inflammation in SpA and IBD, we review and compare genome-wide linkage and genetic association data obtained for SpA and IBD.
\end{abstract}

Keywords: Spondyloarthropathy, Crohn's disease, genetic susceptibility, NOD2, HLA-B27, IL23R.

Spondyloarthropathy (SpA) and inflammatory bowel disease (IBD) are chronic inflammatory conditions in which the initiating events are complex. In SpA, the axial skeleton, the sacroiliac joints and, to a lesser degree, peripheral joints become inflamed, whereas in IBD involving Crohn's disease (CD) and ulcerative colitis (UC), the intestine is the primary site of inflammation. The estimated prevalence in Western countries is $0.3-2 \%$ for $\mathrm{SpA}$ and $0.1-0.3 \%$ for IBD. The unity between $\mathrm{SpA}$ and IBD is illustrated by a strong clinical as well as molecular overlap. The first symptoms present themselves in early adulthood, usually before the age of 30 , but early childhood and late onset disease occur sporadically. Medical treatment is mainly based on diminishing the inflammation and maintaining the remission states. Spondyloarthropathy is a heterogeneous group generally divided into 5 disease categories: ankylosing spondylitis (AS), reactive arthritis (ReA), psoriatic arthritis (PsA), SpA associated with IBD (SpA-IBD) and undifferentiated SpA. In the SpAIBD group, patients suffer from clinically overt CD or UC. However, the gut is also an important site of inflammation in patients belonging to the other SpA disease categories. In ileocolonoscopic studies of SpA patients, histological signs of gut inflammation were found in more than half of the subjects, while this was not seen in any other inflammatory joint disease [1-6]. Generally, no clinical intestinal manifestations were present. In addition, remission of joint inflammation was always linked with a disappearance of gut inflammation [7]. With histology, two types of inflammation are distin-

\footnotetext{
*Address correspondence to this author at the Department of Gastroenterology, Ghent University Hospital, De Pintelaan 185 3K12IE, B-9000 Gent, Belgium; Tel: +3293322064; Fax: +3293324984;

E-mail: debby.laukens@ugent.be
}

guished: acute inflammation resembling infectious enterocolitis, and chronic inflammation more suggestive of early CD [8]. In a long-term follow-up study of SpA patients, it was shown that a high percentage of patients initially diagnosed with chronic gut inflammation developed clinical CD [7]. The presence of early CD-related immune changes in the gut of patients with SpA and an increase in antigen handling and presentation was shown [9-16]. On the other hand, joint involvement is observed in $10-20 \%$ of IBD patients, whereas the presence of radiological sacroiliitis is much more common [17]. In $90 \%$ of IBD patients with articular involvement, their symptoms can be classified as SpA [18]. Interestingly, therapeutic intervention in SpA and IBD can have a positive influence on both the articular and the intestinal inflammation $[19,20]$.

A strong genetic predisposition was shown for $\mathrm{CD}$ and $\mathrm{SpA}$, illustrated by familial clustering and a high recurrence risk in relatives of affected individuals [21,22]. The concordance rate in monozygotic twins is $50-75 \%$ for $\mathrm{SpA}$ [22] and $20-50 \%$ for CD [21], which is significantly higher than in dizygotic twins. Since these numbers do not reach $100 \%$, it is well understood that genes as well as environmental triggers interact to set off the diseases. For a long time, a very strong association with the major histocompatibility complex I allele $H L A-B 27$ was described for SpA. The genetic component for $\mathrm{UC}$ is less than for $\mathrm{CD}[21,23]$; therefore this review will mainly focus on data obtained for $\mathrm{CD}$.

The vast majority of genetic research in SpA and $\mathrm{CD}$ focuses on the individual disease. The presence of shared clinical and pathological features between SpA and IBD, however, encourages the search for common genetic aberrations. To gain insight into common susceptibility for SpA and IBD, we compared genome-wide linkage and association 
data, and focused on chromosomal loci that are linked with both diseases. Secondly, association studies of the most important genes were compared and discussed.

\section{FAMILIAL CLUSTERING OF SPONDYLOARTHRO- PATHY AND INFLAMMATORY BOWEL DISEASE}

In addition to the co-occurrence of SpA and IBD within one patient, these diseases have a high tendency to cluster within families. Several isolated reports of mixed SpA/IBD families exist [24-28], though no systematic estimate within families has been reported to date. In Table 1, the number of IBD patients among relatives of SpA probands was deducted from other family studies [29-34]. The frequency of IBD in these families ranges from 4 to $10 \%$. In two studies, a disturbed male to female ratio was found [29, 30]. Although no sex difference exists in sporadic or familial IBD [35, 36], linkage to the $\mathrm{X}$ chromosome was found twice $[37,38]$. Moreover, an increase in maternal transmission was shown in non-Jewish parent-child pairs [39], which was also described in mixed UC/CD families [40]. Whether this sex bias is caused by true genetic association or by imprinting of the $\mathrm{X}$ chromosome is not clear.

Familial SpA and IBD is suspected to be genetically more homogenous than sporadic cases. For CD, an earlier age of onset and a higher frequency of exclusively colonic disease was shown in familial cases [41-45]. The familial form of $\mathrm{AS}$ is associated with a milder disease phenotype [46], and high heritability of disease severity was shown [47, 48]. To what extent these observations hold true in mixed $\mathrm{SpA} / \mathrm{IBD}$ families is not known.

Taken together, these numbers indicate a significant increase in the co-occurrence of SpA and IBD within families, and emphasize the importance of family history as a risk factor for the development of SpA and/or IBD. In addition to a genetic component, shared environmental factors such as microbial agents or eating habits in some families cannot be ruled out as specific triggers of the disease [41, 49]. Nevertheless, mixed SpA/IBD families can be extremely useful for the identification of new common risk factors involved in both pathologies.

\section{GENETIC MODELS FOR SPA AND IBD SUSCEPTI- BILITY}

The question of how many genes are involved in individual genetic susceptibility to SpA and IBD, what degree of penetrance they posses and how they interact remains. Major genes are, by definition, those that lead to the phenotype in most cases, while minor genes are less penetrant and more vulnerable to environmental triggers.

Genome-wide linkage analyses in SpA and CD always result in more than one locus, which suggests an association with more than one chromosomal region and, thus, different genes. Two models that are not mutually exclusive are proposed here, each based on a division between familial and sporadic cases.

The elevated risk of relatives of $\mathrm{SpA}$ and $\mathrm{CD}$ patients developing disease suggests a model where SpA/CD etiology is reliant on a major gene (Fig. 1, model 1), e.g. a gene predisposing for "overactive inflammation", with independent major genes acting to develop inflammation at a specific site, the intestine for $\mathrm{CD}$ and the axial skeleton for SpA. In this model, different major genes can lead to similar phenotypes, leading to genetic heterogeneity. Especially for the "inflammation" phenotype, every gene within the inflammatory pathway can possibly be involved in genetic susceptibility for overactive or non-self-limiting inflammation. Additional environment-sensitive minor genes independently influence the disease subphenotypes, e.g. colonic or ileal involvement in CD. Disease location in $\mathrm{CD}$ is, indeed, highly genetically determined, since this feature is relatively stable within families and is highly concordant in monozygotic twins [50]. Recently, it was suggested that genetic predisposition for familial SpA as a group is due to a shared component, which fits with this model. Indeed, detailed phenotypic studies in SpA multiplex families reported some unexpected findings, most notably the lack of clustering of most manifestations of SpA [30, 31, 51]. In this model, the variation within the SpA concept could be explained as the influence of minor genes acting on the overall SpA phenotype.

On the other hand, most SpA and CD patients are sporadic cases without any diseased relatives. They probably result from a combination of less penetrant minor effects of widespread genetic determinants. A second model states that disease occurs when a specific combination of genes act together (Fig. 1, model 2). On top, independent minor genes influence the disease phenotype. In this way, overlapping diseases such as $\mathrm{CD}$ and $\mathrm{SpA}$ can be easily explained. A simple addition of a risk factor in a patient with SpA could lead to intestinal inflammation resembling CD. For example, we showed that common $C D$-associated variations in the NOD2 gene are more frequently found in SpA patients with CD-like subclinical chronic gut inflammation [52]. This gene

Table 1. Number of IBD Patients in SpA Multiplex Families

\begin{tabular}{|c|c|c|c|c|}
\hline Number of SpA Patients in Multiplex Families & Type of Study & $n \operatorname{IBD}(\%)$ & Male:Female & Ref \\
\hline 539 & Phenotype analysis & $25(4.6)$ & $8: 17 *$ & {$[29]$} \\
\hline 188 & HLA analysis/transmission & $8(4.2)$ & ND & [34] \\
\hline 445 (AS only) & Whole-genome scan & ND (9) & ND & [32] \\
\hline 393 (AS only) & Whole-genome scan & $40(10.2)$ & ND & {$[33]$} \\
\hline 91 & Phenotype segregation & $8(8.8)$ & ND & [31] \\
\hline 329 & Phenotype analysis & $17(5.2)$ & $4: 13 *$ & {$[30]$} \\
\hline
\end{tabular}

*Significant difference.

ND: not determined or not cited. 
MODEL 1:

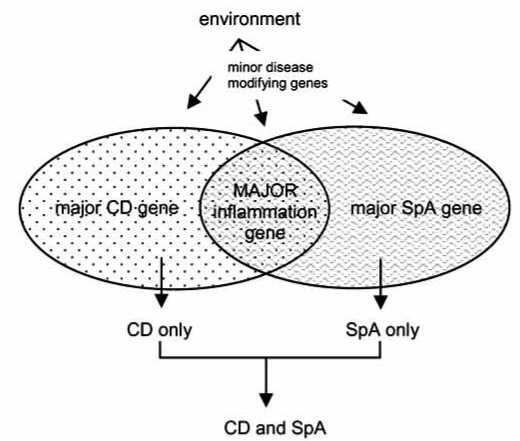

MODEL 2:
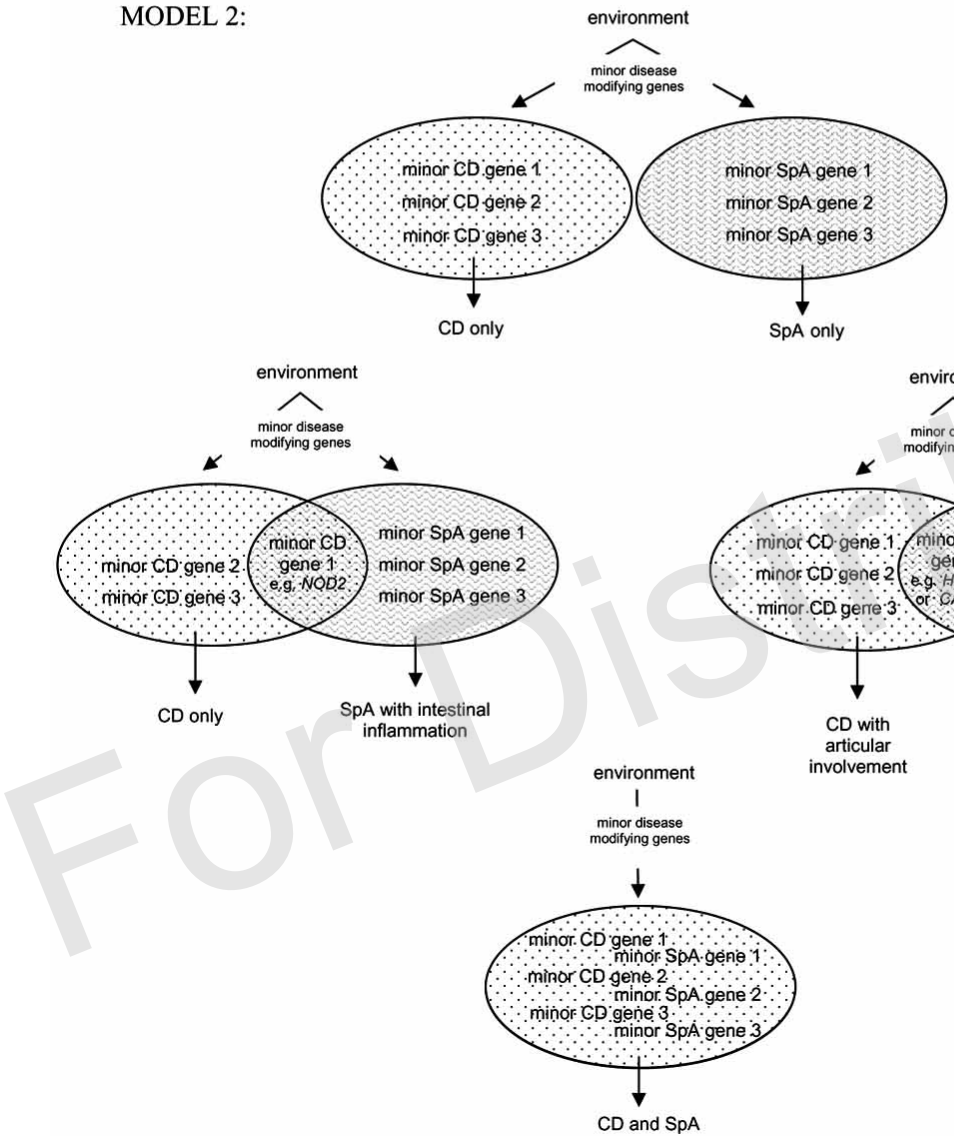

Fig. (1). Two putative models to explain the shared genetic susceptibility for SpA and CD. (A) The first model is based on families where both SpA and CD are found. A major gene (Major inflammation gene) is responsible for overactive or persistent inflammation, while independent major genes dictate where the inflammation is typically found, the joints (Major SpA gene) or the intestine (Major CD gene). If the inflammation gene acts together with one of the other two genes, pure $\mathrm{CD}$ or $\mathrm{SpA}$ is expressed. If, however, the three major genes are present in the patient, he will suffer from both SpA and CD. In addition, independent environment-sensitive minor genes contribute to the overall outcome of the disease in each patient. (B) The second model is probably more applicable to sporadic cases. In this graphical representation, the combination of three genes (although this number is purely speculative) is needed to set up either SpA or CD, with environmental factors influencing the disease phenotype. These genes can act independently of each other to produce a specific phenotype in each patient. For example, if a mutation in the NOD2 gene is present in a patient carrying the combination of the three SpA genes, he will suffer from the chronic gut inflammation phenotype. Similarly, a patient carrying the three genes that set up CD together with the $H L A-B 27$ allele, he will have articular complaints. In the extreme case where all six genes are present, the patient will have both full-blown SpA and CD at some point in his lifetime, depending on additional environmental factors.

\section{BULLET POINTS}

- $\quad$ The frequent co-occurrence of SpA and IBD within a patient and within families suggests shared genetic susceptibility.

- $\quad$ Good candidate genes for such mutual susceptibility are those that are located within loci which have been identified in genome scans of both SpA and IBD. These include IL23R, CTLA4, TNF and TLR4.

- The study of animal models that develop typical features of SpA and IBD provide interesting data of how these diseases can be related or how they are initiated. 
is thus a minor gene, which could lead to overt CD in those SpA patients who carry additional minor gene interactions. Similarly, the SpA-associated HLA-B27 allele is more frequent in IBD patients with associated articular manifestations.

\section{COMMON GENETIC DETERMINANTS OF SPONDY- LOARTHROPATHY AND INFLAMMATORY BOW- EL DISEASE}

The clinical and molecular overlap between SpA and IBD and familial clustering in multiplex families argue for a genetic link between the two diseases. Today, powerful genetic tools can be adopted to find causally important diseaseassociated genes. Genome-wide linkage and association scans provide insights into the position and number of potentially interesting chromosomal regions linked with the disease. Case-control association studies of mutations/polymorphisms within interesting candidate genes is another approach to find causally important gene aberrations; however, this method is not hypothesis-free and depends on other available information, either positional (because it is located within a known locus) or functional (because of known properties of the encoded protein). In the next section, we compile the known loci and positional candidate gene association studies for SpA and IBD.

\section{Genome-Wide Scans for SpA and IBD}

For IBD, 17 genome-wide scans have been performed [37, 53-68]. More than 20 loci were identified with suggestive or significant linkage for CD, UC or IBD in general, and many of them have been independently replicated (IBD1-9, 3q, 4q, 6q, $7 q, 8 q, 10 p, 22 q, X p)$. Four genome-wide scans have been performed for SpA [32, 33, 69, 70], which was recently reviewed by Brown [71]. In addition, a meta-analysis using these four reports was compiled [72], and one study focused on the heritability of age at symptom onset, disease activity, and functional impairment in AS [73]. Three of the four genome-wide scans were performed on isolated AS, which might not be ideal. As discussed earlier, the SpA family is suspected to share susceptibility factors in spite of obvious subclassification.

Interestingly, thirteen chromosomal regions that were identified in one of the genome-wide scans are shared between SpA and IBD (located at 1p, 1q, 2q, 3p, 5q, 6p, 16p, $16 q, 19 p$ and $19 q$, Table 2). These regions, therefore, are good candidates to look for new genes contributing to com-

Table 2. Summary of Chromosomal Loci Identified in Genome-Wide Scans Shared Between CD and SpA

\begin{tabular}{|c|c|c|c|c|c|c|}
\hline Shared Locus & Chromosome & \multicolumn{2}{|c|}{ SpA } & \multicolumn{2}{|l|}{ IBD } & Candidate Genes \\
\hline \multirow{2}{*}{1} & & -1 & & $1 \mathrm{p} 32$ & {$[58]$} & \\
\hline & 1 & 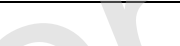 & $\sqrt{1}$ & $1 \mathrm{p} 33-32.3$ & {$[64]$} & \\
\hline 2 & & $1 \mathrm{p} 36.13$ & [69] & $1 \mathrm{p} 36.13-36.11$ & {$[66]$} & \\
\hline \multirow[t]{2}{*}{4} & 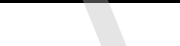 & $1 \mathrm{q} 44$ & [69] & $1 q 43-q 44$ & [37] & \\
\hline & V & $1 \mathrm{q} 44$ & {$[32]$} & & & \\
\hline 5 & Chr2 & $2 q 31.1-34$ & [69] & $2 \mathrm{q} 32.3$ & {$[65]$} & CTLA4 \\
\hline 6 & Chr3 & $3 p 14.2-13$ & {$[33]$} & $3 \mathrm{p} 14.2-14.1$ & {$[68]$} & \\
\hline \multirow[t]{4}{*}{8} & Chr6 & $6 \mathrm{p} 22.3-12.1$ & [69] & $6 \mathrm{p}$ (NOD2 stratified) & {$[62]$} & $T N F, T A P 2, H L A-B 27, S L C 22 A 4$ \\
\hline & & $6 \mathrm{p} 24.3-22.2$ & [32] & $6 \mathrm{p} 22.2$ & [54] & \\
\hline & & $6 \mathrm{p} 25.1-22.3$ & [33] & $6 \mathrm{p} 22.2-21.2$ & {$[68]$} & \\
\hline & & $6 \mathrm{p} 22.2$ & {$[70]$} & $6 \mathrm{p} 23-22.3-22.2$ & {$[37]$} & \\
\hline 9 & & $6 q 25.2-26$ & {$[33]$} & $6 q 25.2-26$ & {$[54]$} & \\
\hline \multirow[t]{2}{*}{10} & Chr16 & $16 \mathrm{p} 12.1$ & [69] & $16 \mathrm{p} 13.13$ & [66] & \\
\hline & & & & 16p11.2-12.1(FM) & [53] & \\
\hline \multirow[t]{2}{*}{11} & & $16 \mathrm{q} 23.1-23.3$ & [69] & $16 \mathrm{q} 21-23.1$ & {$[63]$} & NOD2 \\
\hline & & $16 \mathrm{q} 23.3$ & {$[32]$} & & & \\
\hline
\end{tabular}


mon susceptibility to $\mathrm{SpA}$ and $\mathrm{CD}$. In the next section, we discuss the most interesting candidate genes within these shared regions.

\section{From Loci to Genes: Association Studies for SpA and IBD}

We must bear in mind that, as with all genetic association studies, confirmation in different regionally matched cohorts is crucial. Different findings between association studies are frequently found. This may reflect genuine population differences, or this could mean that the specifically tested variants are not directly involved in etiopathogenesis.

\section{HLA-B27 (6p)}

The SpAs are linked by a common genetic risk factor, the $H L A-B 27$ allele, which is much more prevalent in SpA patients $(75-95 \%)$ than in other rheumatic diseases or in healthy controls $(5-14 \%$ in Caucasians). HLA class I molecules are highly polymorphic glycoproteins specialized for antigen-presenting. They are expressed on the surface of nearly all nucleated cells, where they form stable complexes with antigenic peptides and display them for recognition by $\mathrm{CD}^{+} \mathrm{T}$ cells. Currently, more than 30 allelic variants of the $H L A-B 27$ gene have been identified, and are designated as B*2701 to B*2737 (http://www.anthonynolan.org.uk/HIG/ lists/class1list.html). They differ in one or more amino acids in exons 2 and 3 of the gene [74]. HLA-B*2705, which is considered the ancestral subtype, bears the strongest association with $\mathrm{SpA}$. Not all $\mathrm{B} * 27$ subtypes are associated with SpA and this seems to be highly dependent on the ethnicity of the study population. Moreover, while most of them are risk factors for SpA, others are reported to be protective for the development of the disease, such as $\mathrm{B} * 2706$ and $\mathrm{B} * 2707$. The identification of HLA-B27 subtypes and their association with AS or $\mathrm{SpA}$ in general is the subject of much ongoing research. The $H L A-B 27$ association with $\mathrm{SpA}$ is one of the strongest HLA associations found so far. Based on family and twin studies, it was reported that $H L A-B 27$ contributes to 20 to $50 \%$ of the total genetic risk for the disease [75, 76]. Although this number is high, other genes must be involved in SpA etiology. Moreover, only a small fraction of $H L A-$ $B 27$ positive individuals develop the disease. Which genetic and environmental factors are crucial for eventual development of the disease is not completely understood.

Clinically, SpA pathology in IBD patients is almost identical tot that of idiopathic AS, but there is a difference in HLA-B27 prevalence. Depending on the study population, 6$33 \%$ of IBD patients are positive for HLA-B27 (Table 3) [18, 77-86]. However, it is clear that the prevalence is increased in those IBD patients who also suffer from AS. High preva-

Table 3. HLA-B27 Frequency in IBD and IBD-AS Patients

\begin{tabular}{|c|c|c|c|c|}
\hline Number of Patients & HLA-B27 Positive (\%) & Number of AS Positive Patients in Study & $H L A-B 27$ Positive in IBD-AS Patients (\%) & Ref. \\
\hline \multicolumn{5}{|l|}{$I B D:$} \\
\hline 406 & 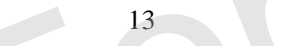 & 15 & 73 & [80] \\
\hline $50 \mathrm{IBP}$ & ND & 14 & 28 & [82] \\
\hline 12 & r & 12 & 33 & [78] \\
\hline 89 & 13 & 4 & 75 & [86] \\
\hline $76 \sqrt{2}$ & 9 & 8 & 25 & [18] \\
\hline \multicolumn{5}{|l|}{$C D:$} \\
\hline 122 & 12 & 9 & 78 & [84] \\
\hline 59 & 10 & ND & ND & [18] \\
\hline 51 & 4 & 10 & 20 & [77] \\
\hline 100 & 6 & 2 & 50 & [79] \\
\hline 78 & 33 & 9 & 100 & [85] \\
\hline 102 & 6 & 9 & 33 & [81] \\
\hline 213 & ND & 18 & 72 & [83] \\
\hline \multicolumn{5}{|l|}{$U C:$} \\
\hline 58 & 19 & 11 & 36 & [77] \\
\hline 17 & 6 & ND & ND & [18] \\
\hline 100 & 14 & 5 & 80 & [79] \\
\hline 84 & 25 & 7 & 100 & [85] \\
\hline
\end{tabular}

IBP: IBD patients with inflammatory back pain.

ND: not determined or not cited. 
lences in these patients are found in some studies (73-100\%), although others reported rather low prevalences (20-50\%) (Table 3). While each study population was extremely small, they all point out that IBD patients carrying the HLA-B27 allele are more likely to develop AS than others who do not possess the antigen. The presence of sacroiliitis in the SpA concept or in CD is not associated with HLA-B27 [81, 84].

\section{NOD2 (16q)}

A strong and highly repeated association with $N O D 2$, a gene encoding an intracellular receptor for bacterial components, was found for $\mathrm{CD}$. Three single nucleotide polymorphisms (SNPs) were independently associated with the disease [87, 88]. Each SNP carries a 2 to 4 -fold increased relative risk if heterozygous, while homozygous or compound heterozygous carriers have a 20 -fold increased risk. Despite the strong association with $\mathrm{CD}$ (frequency up to $50 \%$ in European and North American patients), they are relatively frequent mutations in healthy individuals $(\sim 20 \%)$. The SNPs in NOD2 are not associated with susceptibility to UC; however, an epistatic interaction between NOD2 and the IBD5 haplotype is suspected [89]. This gene is also involved in the etiology of some other diseases, such as graft $v s$ host disease and Blau syndrome [90]. NOD2 is not a risk factor for $\mathrm{SpA}$ [91-96], although one study found an association between one of the SNPs and UC-SpA [93]. Because a locus at 16q has been associated with paternal transmission in PsA [97], the involvement of NOD2 was more frequently studied in this disease. A positive association with PsA was found once [98], but this was not supported by other studies [99-101]. We also could not show an association of NOD2 with SpA in general; however, those patients with subclinical chronic gut inflammation contained a significantly higher number of CD-associated SNPs in NOD2 (38\%), which was comparable to the frequency in $\mathrm{CD}$ patients from the same institution (49\%) [52]. Therefore, we proposed that NOD2 is a determinant of susceptibility to the development of chronic gut inflammation as such. Since this group of SpA patients is at high risk of developing CD over time [7], it is plausible that the combination of a dysfunctional bacterial receptor with other susceptibility genes or environmental triggers in these patients initiates an abnormally strong immune response toward luminal flora or pathogens.

We described a link between NOD2 and the presence of radiographic sacroiliitis in $\mathrm{CD}$ patients, irrespective of overt AS [81]. Seventy-eight percent of CD patients with sacroiliitis were carriers of at least one SNP in NOD2, compared to $48 \%$ of those who were wild type for NOD2. However, in a second multi-center study, this observation could not be repeated [102]. The reason for this inconsistency is not clear. Poor reproducibility of genetic association studies for complex diseases is not uncommon. However, detecting sacroiliitis on radiographs of the sacroiliac joints is difficult and holds a high inter- and intra- observer variability [103].

An interesting underlying trait in IBD is a compromised intestinal permeability [104]. A "leaky" barrier function can lead to excessive bacterial influx, leading to a continuous triggering of the immune response in the gut mucosa. Whether this process is genetically determined is still controversial [105]. However, a primary role for an increase in intestinal permeability was suggested based on the observation that this abnormality is not only present in CD patients, but also in their healthy relatives $[106,107]$. This leaky gut theory was further supported by changes in the unaffected bowel of CD patients [108, 109]. Similarly, an increase in gut permeability was also found in juvenile chronic arthritis [110] and in relatives of patients with AS, irrespective of NSAID intake or disease activity [111-114]. The first genetic evidence of underlying permeability dysfunction in persons carrying a mutated form of NOD2 comes from the observation that one of these mutations is associated with permeability in familial CD patients and their relatives more than in sporadic CD and their relatives $[115,116]$. However, this association was not supported in another study [117], although it is not clear whether familial cases were included in their analysis. Since an increase in gut permeability is not a useful marker for predicting CD development over time, additional genetic components would be of great use to evaluate the risk, especially in relatives of $\mathrm{CD}$ patients.

\section{IL23R (1p)}

Interestingly, the $1 \mathrm{p} 32$ region found in the study of Brown and co-workers has been narrowed down to association with polymorphisms in the receptor for interleukin 23 (IL23R) in CD $[55,58]$. Recently, variants in this gene were studied in AS, and a strong association was found [118, 119]. Moreover, IL23 is highly overexpressed in AS gut biopsies as compared to healthy controls, with levels similar to those found in $\mathrm{CD}$ biopsies [120]. The role of this cytokine and its receptor will be the subject of further study in SpA-IBD.

\section{TNF ( $6 p)$}

Tumor necrosis factor alpha (TNF) is a pro-inflammatory cytokine that provides a rapid form of defense against various infections. However, if this cytokine is produced in excess, it can be fatal to the host. This gene was a strong positional and functional candidate gene for $\mathrm{CD}$ because TNF levels are increased in the serum, mucosa and stool of these patients, while anti-TNF therapy is very efficacious in CD [121]. The production of TNF is under strong genetic influence [122]. As will be discussed in the next paragraph, the level of TNF production in the TNF transgene mouse model is critical for the development of arthritis and colitis. Therefore, the study of promoter polymorphisms influencing TNF dosage in humans seems highly relevant.

Three SNPs in the promoter of TNF (c.-1031C, c.-863A and c.-857T) were associated with susceptibility to $C D$ in a Japanese population [123]. In contrast, none of these SNPs could be associated with IBD in two independent Caucasian populations, while the c.-857C allele was more prevalent in IBD and UC [93]. Interestingly, this variant was also associated with $\mathrm{CD}$ when they left out the common NOD2 allele carriers, meaning that these genes act independently to confer CD susceptibility. Pediatric onset, colonic disease and familial aggregation of $\mathrm{CD}$ was associated with the c.$863 \mathrm{C}>\mathrm{A}$ polymorphism, which is located within a binding site for NFKB in the $T N F$ promoter [124]. Moreover, it was demonstrated that exposure of $293 \mathrm{~T}$ cells to bacterial components stimulates $T N F$ gene transcription as a result of NOD2-induced NFKB activation [125]. When this experiment was repeated in cells containing the NOD2 1007fs variant, the induction of $T N F$ promoter activity was found to be defective. Different combinations of NOD2 and TNF promoter polymorphisms gave rise to distinct TNF transcrip- 
tion levels, which means that NOD2 and TNF promoter polymorphisms interact to exert a functional effect on bacterial induced TNF production. Therefore, this gene-gene interaction may contribute to inter-individual variation in susceptibility to $\mathrm{CD}$.

TNF is in close proximity to the HLA-B locus on chromosome 6 . The search for disease-associated alleles within this region is complicated because of high linkage disequilibrium. One report detected an association between -308 and AS [126]. No association was found among four promoter polymorphisms (located at c.-244, c.-376, c.-238 and c.-308) between AS and controls [127, 128]. The CD-associated promoter polymorphisms have not been tested in SpA. However, for PsA, an association was found for the c.-857 SNP [129].

\section{TLR4 (9q)}

Lipopolysaccharide (LPS), a cell wall component of Gram-negative bacteria, is a major inducer of inflammation, and its signaling is mediated through the cell surface receptor toll-like receptor 4 (TLR4). During intestinal inflammation, TLR4 is up-regulated on epithelial cells, macrophages and dendritic cells, thus providing a first line of defense against enteric Gram-negative bacteria. An association between a polymorphism in the leucine-rich region of TLR4 (c.896A $>$ G, D299G) was reported in a Dutch CD and UC cohort [58]. Allele frequencies of $10.9 \%$ were found in $\mathrm{CD}$ patients, $v s 5 \%$ in healthy controls. The association was replicated three times [130-132], but could not be reproduced in three other studies [133-135]. This mutation was previously linked with a decreased bronchial responsiveness to LPS [136]. However, no functional defect, such as in cytokine release or LPS recognition, has been attributed to heterozygous carriership of this mutant in CD patients [137, 138].

Because TLR4 is in proximity to a linkage peak in $9 \mathrm{q} 32$ 33 and the possibility that AS occurs when Gram- negative gut bacteria interact with HLA-B27, this gene was of potential interest to test for association with AS. A small casecontrol study indeed showed an association [139], but this was not found in two other studies for AS, nor in one for $\operatorname{ReA}$ [140-142].

\section{ANIMAL MODELS TO STUDY THE ARTICULAR AND INTESTINAL ASSOCIATION}

Two animal models, the TNFAARE mice and HLA-B27 rats, share some features of both $\mathrm{CD}$ and SpA. They thus provide a way to study specific biological mechanisms involved in both pathologies. In these models, TNF and HLAB27 (together with the human $\beta 2$-microglobulin) are overexpressed.

The excess production of TNF in SpA and IBD affected tissues and in serum is well known [121, 143]. Moreover, anti-TNF therapy is highly efficient in both diseases. The TNF $\triangle$ ARE mice carry a deletion of AU-rich inhibitory elements of the TNF gene [144]. This results in an increased stability of the TNF mRNA and an increase in constitutive and inducible expression of TNF in circulation and in fibroblasts isolated from the synovium and lung. These mice spontaneously develop transmural ileitis (occasionally proximal colitis) after 8 weeks in the case of heterozygous carriers and show chronic inflammatory polyarthritis at 6-8 weeks. Although the transcription of TNF in the TNF $\triangle$ ARE mice should theoretically be increased in all tissues, it is striking that only extended inflammation is found in the intestine and joints of these mice. Only occasionally do other organs such as lung or liver show some signs of inflammation. This supports the idea that one possible etiopathogenic mechanism in human SpA-IBD is genetically determined overexpression, or lack of repression, of TNF. Therefore, the study of promoter polymorphisms in TNF is very important (see previous section).

The overexpression of the human $H L A-B 27$ allele in rats represents a very specific model, and provides further evidence for a direct causative role of this allele in human SpA and related intestinal inflammation [145]. These rats develop spontaneous colitis, gastritis, peripheral arthritis and occasionally spondylitis. Importantly, some transgenic mice are healthy, depending on the copy number of HLA-B27. Disease only develops if a threshold level of HLA-B27 is reached [146]. This could be one explanation why $H L A-B 27$ carriers do not all develop SpA. In this view, the regulation of this allele is worth studying. Recently, it was shown that crossing healthy HLA-B27 transgenic rats with those containing healthy human $\beta 2$-microglobulin transgenes only results in articular problems and not in intestinal inflammation [147]. This indicates that gut inflammation is not absolutely indicated in HLA-B27 rats, and might suggest that this allele could lead to two different phenotypes in human SpA, depending on other factors.

A big advantage of using animal models is that the initiating event, the time course and potential triggers (e.g. bacteria) can be controlled. Interestingly, the HLA-B27 rats don't develop disease when kept in germ free conditions [148]. This directly implies that environmental stimuli are needed to trigger the onset of the disease. Whether this dependence on microflora is also true for the TNF $\triangle \mathrm{ARE}$ mice is not known.

\section{CONCLUSIONS}

Many complex diseases share overlapping features. Therefore, parallel to the study of genetic susceptibility of the disease in general, subphenotyping in genetic analyses is crucial to understand specific relationships between disorders.

Overlapping chromosomal loci associated with the susceptibility to both SpA and IBD are primary regions of interest in the search for new candidate genes. The association of NOD2 and HLA-B27 with the combined presence of SpA and $\mathrm{CD}$ in patients provides evidence that these are related polygenic conditions that share some, but not all, susceptibility genes. In addition to a better understanding of the occurrence of specific subphenotypes in SpA and IBD, the identification of common susceptibility genes for SpA and IBD could aid in specifically targeting atypical processes in both diseases. Moreover, once a gene is identified, a whole new area of research can provide new insights into its pathology, as has been nicely illustrated for NOD2.

\section{REFERENCES}

[1] De Keyser F, Elewaut D, De Vos M, et al. Bowel inflammation and the spondyloarthropathies. Rheum Dis Clin North Am 1998; 24: 785-813.

[2] Leirisalo-Repo M, Turunen U, Stenman S, Helenius P, Seppala K. High frequency of silent inflammatory bowel disease in spondylarthropathy. Arthritis Rheum 1994; 37: 23-31. 
[3] Mielants H, Veys EM, Cuvelier C, de Vos M. Ileocolonoscopic findings in seronegative spondylarthropathies. $\mathrm{Br} \mathrm{J}$ Rheumatol 1988; 27 Suppl 2: 95-105.

[4] Mielants H, Veys EM, Cuvelier C, et al. The evolution of spondyloarthropathies in relation to gut histology. II. Histological aspects. J Rheumatol 1995; 22: 2273-8.

[5] Mielants H, Veys EM, Cuvelier C, et al. The evolution of spondyloarthropathies in relation to gut histology. III. Relation between gut and joint. J Rheumatol 1995; 22: 2279-84.

[6] Mielants H, Veys EM, De Vos M, et al. The evolution of spondyloarthropathies in relation to gut histology. I. Clinical aspects. J Rheumatol 1995; 22: 2266-72.

[7] De Vos M, Mielants H, Cuvelier C, Elewaut A, Veys E. Long-term evolution of gut inflammation in patients with spondyloarthropathy. Gastroenterology 1996; 110: 1696-703.

[8] Cuvelier C, Barbatis C, Mielants H, De Vos M, Roels H, Veys E. Histopathology of intestinal inflammation related to reactive arthritis. Gut 1987; 28: 394-401.

[9] Demetter P, Van Huysse JA, De Keyser F, et al. Increase in lymphoid follicles and leukocyte adhesion molecules emphasizes a role for the gut in spondyloarthropathy pathogenesis. J Pathol 2002; 198: 517-22.

[10] Elewaut D, Van Damme N, Baeten D, De Vos M. Intestinal mucosa of patients with spondyloarthropathy is enriched with $\mathrm{T}$ cells carrying $\alpha E \beta 7$ integrin, even in the absence of histologically defined inflammation. Gastroenterology 1999; 116: G3069.

[11] Van Damme N, De Keyser F, Demetter P, et al. The proportion of Th1 cells, which prevail in gut mucosa, is decreased in inflammatory bowel syndrome. Clin Exp Immunol 2001; 125: 383-90.

[12] Van Damme N, De Vos M, Baeten D, et al. Flow cytometric analysis of gut mucosal lymphocytes supports an impaired Th1 cytokine profile in spondyloarthropathy. Ann Rheum Dis 2001; 60: 495-9.

[13] Van Damme N, Elewaut D, Baeten D, et al. Gut mucosal T cell lines from ankylosing spondylitis patients are enriched with alphaEbeta7 integrin. Clin Exp Rheumatol 2001; 19: 681-7.

[14] Baeten D, Demetter P, Cuvelier CA, et al. Macrophages expressing the scavenger receptor CD163: a link between immune alterations of the gut and synovial inflammation in spondyloarthropathy. $\mathbf{J}$ Pathol 2002; 196: 343-50.

[15] Demetter P, De Vos M, Van Huysse JA, et al. Colon mucosa of patients both with spondyloarthritis and Crohn's disease is enriched with macrophages expressing the scavenger receptor CD163. Ann Rheum Dis 2005; 64: 321-4.

[16] Demetter P, De Vos M, Van Damme N, et al. Focal up-regulation of E-cadherin-catenin complex in inflamed bowel mucosa but reduced expression in ulcer-associated cell lineage. Am J Clin Pathol 2000; 114: 364-70.

[17] De Vos M. Review article: joint involvement in inflammatory bowel disease. Aliment Pharmacol Ther 2004; 20 Suppl 4: 36-42.

[18] de Vlam K, Mielants H, Cuvelier C, De Keyser F, Veys EM, De Vos M. Spondyloarthropathy is underestimated in inflammatory bowel disease: prevalence and HLA association. J Rheumatol 2000; $27: 2860-5$

[19] Mielants H, Veys EM, Cuvelier C, De Vos M. Course of gut inflammation in spondylarthropathies and therapeutic consequences. Baillieres Clin Rheumatol 1996; 10: 147-64.

[20] Van den Bosch F, Kruithof E, De Vos M, De Keyser F, Mielants H. Crohn's disease associated with spondyloarthropathy: effect of TNF-alpha blockade with infliximab on articular symptoms. Lancet 2000; 356: 1821-2.

[21] Halme L, Paavola-Sakki P, Turunen U, Lappalainen M, Farkkila M, Kontula K. Family and twin studies in inflammatory bowel disease. World J Gastroenterol 2006; 12: 3668-72.

[22] Brown MA, Laval SH, Brophy S, Calin A. Recurrence risk modelling of the genetic susceptibility to ankylosing spondylitis. Ann Rheum Dis 2000; 59: 883-6.

[23] Tysk C. Genetic susceptibility in Crohn's disease--review of clinical studies. Eur J Surg 1998; 164: 893-6.

[24] Gilvarry J, Keeling F, Fielding JF. Sibship Crohn's disease and ankylosing spondylitis. J Clin Gastroenterol 1990; 12: 711-2.

[25] Hickling P, Bird-Stewart JA, Young JD, Wright V. Crohn's spondylitis: a family study. Ann Rheum Dis 1983; 42: 106-7.

[26] Mielants H, Veys EM, Joos R, Suykens S, Cuvelier C, De Vos M. Familial aggregation in seronegative spondyloarthritis of enterogenic origin. A family study. J Rheumatol 1986; 13: 126-8.
[27] Czeizel AE. Familial aggregation of Crohn's disease and ankylosing spondylitis in a mother and her son. J Clin Gastroenterol 1992; 14: $349-50$.

[28] Davis P. Quantitative sacroiliac scintigraphy in ankylosing spondylitis and Crohn's disease: a single family study. Ann Rheum Dis 1979; 38: 241-3.

[29] Porcher R, Said-Nahal R, D'Agostino MA, Miceli-Richard C, Dougados M, Breban M. Two major spondylarthropathy phenotypes are distinguished by pattern analysis in multiplex families. Arthritis Rheum 2005; 53: 263-71.

[30] Said-Nahal R, Miceli-Richard C, Berthelot JM, et al. The familial form of spondylarthropathy: a clinical study of 115 multiplex families. Groupe Francais d'Etude Genetique des Spondylarthropathies. Arthritis Rheum 2000; 43: 1356-65.

[31] Said-Nahal R, Miceli-Richard C, D'Agostino MA, et al. Phenotypic diversity is not determined by independent genetic factors in familial spondylarthropathy. Arthritis Rheum 2001; 45: 478-84.

[32] Laval SH, Timms A, Edwards S, et al. Whole-genome screening in ankylosing spondylitis: evidence of non-MHC geneticsusceptibility loci. Am J Hum Genet 2001; 68: 918-26.

[33] Zhang G, Luo J, Bruckel J, et al. Genetic studies in familial ankylosing spondylitis susceptibility. Arthritis Rheum 2004; 50: 224654.

[34] Said-Nahal R, Miceli-Richard C, Gautreau C, et al. The role of HLA genes in familial spondyloarthropathy: a comprehensive study of 70 multiplex families. Ann Rheum Dis 2002; 61: 201-6.

[35] Ekbom A, Helmick C, Zack M, Adami HO. The epidemiology of inflammatory bowel disease: a large, population-based study in Sweden. Gastroenterology 1991; 100: 350-8.

[36] Carbonnel F, Macaigne G, Beaugerie L, Gendre JP, Cosnes J. Crohn's disease severity in familial and sporadic cases. Gut 1999; 44: 91-5.

[37] Hampe J, Schreiber S, Shaw SH, et al. A genomewide analysis provides evidence for novel linkages in inflammatory bowel disease in a large European cohort. Am J Hum Genet 1999; 64: 80816.

[38] Vermeire S, Satsangi J, Peeters M, et al. Evidence for inflammatory bowel disease of a susceptibility locus on the $\mathrm{X}$ chromosome. Gastroenterology 2001; 120: 834-40.

[39] Akolkar PN, Gulwani-Akolkar B, Heresbach D, et al. Differences in risk of Crohn's disease in offspring of mothers and fathers with inflammatory bowel disease. Am J Gastroenterol 1997; 92: 2241-4.

[40] Lee JC, Bridger S, McGregor C, Macpherson AJ, Jones JE. Why children with inflammatory bowel disease are diagnosed at a younger age than their affected parent. Gut 1999; 44: 808-11.

[41] Colombel JF, Grandbastien B, Gower-Rousseau C, et al. Clinical characteristics of Crohn's disease in 72 families. Gastroenterology 1996; 111: 604-7.

[42] Cottone M, Brignola C, Rosselli M, et al. Relationship between site of disease and familial occurrence in Crohn's disease. Dig Dis Sci 1997; 42: 129-32.

[43] Dorn SD, Abad JF, Panagopoulos G, Korelitz BI. Clinical characteristics of familial vs sporadic Crohn's disease using the Vienna Classification. Inflamm Bowel Dis 2004; 10: 201-6.

[44] Halme L, Turunen U, Helio T, et al. Familial and sporadic inflammatory bowel disease: comparison of clinical features and serological markers in a genetically homogeneous population. Scand J Gastroenterol 2002; 37: 692-8.

[45] Paul T, Birnbaum A, Pal DK, et al. Distinct phenotype of early childhood inflammatory bowel disease. J Clin Gastroenterol 2006; 40: 583-6.

[46] Calin A, Kennedy LG, Edmunds L, Will R. Familial vs sporadic ankylosing spondylitis. Two different diseases? Arthritis Rheum 1993; 36: 676-81.

[47] Hamersma J, Cardon LR, Bradbury L, et al. Is disease severity in ankylosing spondylitis genetically determined? Arthritis Rheum 2001; 44: 1396-400.

[48] Brophy S, Hickey S, Menon A, et al. Concordance of disease severity among family members with ankylosing spondylitis? J Rheumatol 2004; 31: 1775-8.

[49] Laharie D, Debeugny S, Peeters M, et al. Inflammatory bowel disease in spouses and their offspring. Gastroenterology 2001; 120: 816-9.

[50] Halfvarson J, Bodin L, Tysk C, Lindberg E, Jarnerot G. Inflammatory bowel disease in a Swedish twin cohort: a long-term follow-up 
of concordance and clinical characteristics. Gastroenterology 2003; 124: 1767-73.

[51] Breban M, Said-Nahal R, Hugot JP, Miceli-Richard C. Familial and genetic aspects of spondyloarthropathy. Rheum Dis Clin North Am 2003; 29: 575-94.

[52] Laukens D, Peeters H, Marichal D, et al. CARD15 gene polymorphisms in patients with spondyloarthropathies identify a specific phenotype previously related to Crohn's disease. Ann Rheum Dis 2005; 64: 930-5.

[53] Cavanaugh J. International collaboration provides convincing linkage replication in complex disease through analysis of a large pooled data set: Crohn disease and chromosome 16. Am J Hum Genet 2001; 68: 1165-71.

[54] Barmada MM, Brant SR, Nicolae DL, et al. A genome scan in 260 inflammatory bowel disease-affected relative pairs. Inflamm Bowel Dis 2004; 10: 513-20.

[55] Duerr RH, Taylor KD, Brant SR, et al. A genome-wide association study identifies IL23R as an inflammatory bowel disease gene. Science 2006; 314: 1461-3.

[56] Hampe J, Franke A, Rosenstiel P, et al. A genome-wide association scan of nonsynonymous SNPs identifies a susceptibility variant for Crohn disease in ATG16L1. Nat Genet 2007; 39: 207-11.

[57] Hugot JP, Laurent-Puig P, Gower-Rousseau C, et al. Mapping of a susceptibility locus for Crohn's disease on chromosome 16. Nature 1996; 379: 821-3.

[58] Libioulle C, Louis E, Hansoul S, et al. Novel crohn disease locus identified by genome-wide association maps to a gene desert on 5p13.1 and modulates expression of PTGER4. PLoS Genet 2007; 3: e58.

[59] Ma Y, Ohmen JD, Li Z, et al. A genome-wide search identifies potential new susceptibility loci for Crohn's disease. Inflamm Bowel Dis 1999; 5: 271-8.

[60] Paavola-Sakki P, Ollikainen V, Helio T, et al. Genome-wide search in Finnish families with inflammatory bowel disease provides evidence for novel susceptibility loci. Eur J Hum Genet 2003; 11: 112 20.

[61] Satsangi J, Parkes M, Louis E, et al. Two stage genome-wide search in inflammatory bowel disease provides evidence for susceptibility loci on chromosomes 3, 7 and 12. Nat Genet 1996; 14 : 199-202.

[62] Shaw SH, Hampe J, White R, Mathew CG, Curran ME, Schreiber $\mathrm{S}$. Stratification by CARD15 variant genotype in a genome-wide search for inflammatory bowel disease susceptibility loci. Hum Genet 2003; 113: 514-21.

[63] van Heel DA, Dechairo BM, Dawson G, et al. The IBD6 Crohn's disease locus demonstrates complex interactions with CARD15 and IBD5 disease-associated variants. Hum Mol Genet 2003; 12: 256975 ..

[64] Vermeire S, Rutgeerts P, Van Steen K, et al. Genome wide scan in a Flemish inflammatory bowel disease population: support for the IBD4 locus, population heterogeneity, and epistasis. Gut 2004; 53: 980-6.

[65] Duerr RH, Barmada MM, Zhang L, Pfutzer R, Weeks DE. Highdensity genome scan in Crohn disease shows confirmed linkage to chromosome 14q11-12. Am J Hum Genet 2000; 66: 1857-62.

[66] Cho JH, Nicolae DL, Gold LH, et al. Identification of novel susceptibility loci for inflammatory bowel disease on chromosomes $1 \mathrm{p}, 3 \mathrm{q}$, and 4q: evidence for epistasis between $1 \mathrm{p}$ and IBD1. Proc Natl Acad Sci U S A 1998; 95: 7502-7.

[67] Rioux JD, Xavier RJ, Taylor KD, et al. Genome-wide association study identifies new susceptibility loci for Crohn disease and implicates autophagy in disease pathogenesis. Nat Genet 2007; 39: 596-604.

[68] Rioux JD, Silverberg MS, Daly MJ, et al. Genomewide search in Canadian families with inflammatory bowel disease reveals two novel susceptibility loci. Am J Hum Genet 2000; 66: 1863-70.

[69] Brown MA, Pile KD, Kennedy LG, et al. A genome-wide screen for susceptibility loci in ankylosing spondylitis. Arthritis Rheum 1998; 41: 588-95

[70] Miceli-Richard C, Zouali H, Said-Nahal R, et al. Significant linkage to spondyloarthropathy on 9q31-34. Hum Mol Genet 2004; 13 : 1641-8.

[71] Brown MA. Non-major-histocompatibility-complex genetics of ankylosing spondylitis. Best Pract Res Clin Rheumatol 2006; 20: 611-21.
[72] Lee YH, Rho YH, Choi SJ, Ji JD, Song GG. Ankylosing spondylitis susceptibility loci defined by genome-search meta-analysis. J Hum Genet 2005; 50: 453-9.

[73] Brown MA, Brophy S, Bradbury L, et al. Identification of major loci controlling clinical manifestations of ankylosing spondylitis. Arthritis Rheum 2003; 48: 2234-9.

[74] Reveille JD. Major histocompatibility genes and ankylosing spondylitis. Best Pract Res Clin Rheumatol 2006; 20: 601-9.

[75] Brown MA, Kennedy LG, MacGregor AJ, et al. Susceptibility to ankylosing spondylitis in twins: the role of genes, HLA, and the environment. Arthritis Rheum 1997; 40: 1823-8.

[76] Rubin LA, Amos CI, Wade JA, et al. Investigating the genetic basis for ankylosing spondylitis. Linkage studies with the major histocompatibility complex region. Arthritis Rheum 1994; 37: 1212-20.

[77] Dekker-Saeys BJ, Meuwissen SG, Van Den Berg-Loonen EM, De Haas WH, Agenant D, Tytgat GN. Ankylosing spondylitis and inflammatory bowel disease. II. Prevalence of peripheral arthritis, sacroiliitis, and ankylosing spondylitis in patients suffering from inflammatory bowel disease. Ann Rheum Dis 1978; 37: 33-5.

[78] Enlow RW, Bias WB, Arnett FC. The spondylitis of inflammatory bowel disease. Evidence for a non-HLA linked axial arthropathy. Arthritis Rheum 1980; 23: 1359-65.

[79] Mallas EG, Mackintosh P, Asquith P, Cooke WT. Histocompatibility antigens in inflammatory bowel disease. Their clinical significance and their association with arthropathy with special reference to HLA-B27 (W27). Gut 1976; 17: 906-10.

[80] Palm O, Moum B, Ongre A, Gran JT. Prevalence of ankylosing spondylitis and other spondyloarthropathies among patients with inflammatory bowel disease: a population study (the IBSEN study). J Rheumatol 2002; 29: 511-5.

[81] Peeters H, Vander Cruyssen B, Laukens D, et al. Radiological sacroiliitis, a hallmark of spondylitis, is linked with CARD15 gene polymorphisms in patients with Crohn's disease. Ann Rheum Dis 2004; 63: 1131-4.

[82] Podswiadek M, Punzi L, Stramare R, et al. [The prevalence of radiographic sacroiliitis in patients affected by inflammatory bowel disease with inflammatory low back pain]. Reumatismo 2004; 56: 110-3.

[83] Purrmann J, Zeidler H, Bertrams J, et al. HLA antigens in ankylosing spondylitis associated with Crohn's disease. Increased frequency of the HLA phenotype B27,B44. J Rheumatol 1988; 15: 1658-61.

[84] Steer S, Jones H, Hibbert J, et al. Low back pain, sacroiliitis, and the relationship with HLA-B27 in Crohn's disease. J Rheumatol 2003; 30: 518-22.

[85] Turkcapar N, Toruner M, Soykan I, et al. The prevalence of extraintestinal manifestations and HLA association in patients with inflammatory bowel disease. Rheumatol Int 2006; 26: 663-8.

[86] Hyla JF, Franck WA, Davis JS. Lack of association of HLA B27 with radiographic sacroiliitis in inflammatory bowel disease. $\mathrm{J}$ Rheumatol 1976; 3: 196-200.

[87] Hugot JP, Chamaillard M, Zouali H, et al. Association of NOD2 leucine-rich repeat variants with susceptibility to Crohn's disease. Nature 2001; 411: 599-603.

[88] Ogura Y, Bonen DK, Inohara N, et al. A frameshift mutation in NOD2 associated with susceptibility to Crohn's disease. Nature 2001; 411: 603-6.

[89] McGovern DP, Van Heel DA, Negoro K, Ahmad T, Jewell DP. Further evidence of IBD5/CARD15 (NOD2) epistasis in the susceptibility to ulcerative colitis. Am J Hum Genet 2003; 73: 1465-6.

[90] Henckaerts L, Vermeire S. NOD2/CARD15 disease associations other than Crohn's disease. Inflamm Bowel Dis 2007; 13: 235-41.

[91] Ferreiros-Vidal I, Amarelo J, Barros F, Carracedo A, Gomez-Reino JJ, Gonzalez A. Lack of association of ankylosing spondylitis with the most common NOD2 susceptibility alleles to Crohn's disease. J Rheumatol 2003; 30: 102-4.

[92] Kim TH, Rahman P, Jun JB, et al. Analysis of CARD15 polymorphisms in Korean patients with ankylosing spondylitis reveals absence of common variants seen in western populations. J Rheumatol 2004; 31: 1959-61.

[93] Crane AM, Bradbury L, van Heel DA, et al. Role of NOD2 variants in spondylarthritis. Arthritis Rheum 2002; 46: 1629-33.

[94] D'Amato M. The Crohn's associated NOD2 3020InsC frameshift mutation does not confer susceptibility to ankylosing spondylitis. J Rheumatol 2002; 29: 2470-1. 
[95] Miceli-Richard C, Zouali H, Lesage S, et al. CARD15/NOD2 analyses in spondylarthropathy. Arthritis Rheum 2002; 46: 1405-6.

[96] van der Paardt M, Crusius JB, de Koning MH, et al. CARD15 gene mutations are not associated with ankylosing spondylitis. Genes Immun 2003; 4: 77-8.

[97] Karason A, Gudjonsson JE, Upmanyu R, et al. A susceptibility gene for psoriatic arthritis maps to chromosome 16q: evidence for imprinting. Am J Hum Genet 2003; 72: 125-31.

[98] Rahman P, Bartlett S, Siannis F, et al. CARD15: a pleiotropic autoimmune gene that confers susceptibility to psoriatic arthritis. Am J Hum Genet 2003; 73: 677-81.

[99] Jenisch S, Hampe J, Elder JT, et al. CARD15 mutations in patients with plaque-type psoriasis and psoriatic arthritis: lack of association. Arch Dermatol Res 2006; 297: 409-11.

[100] Giardina E, Novelli G, Costanzo A, et al. Psoriatic arthritis and CARD15 gene polymorphisms: no evidence for association in the Italian population. J Invest Dermatol 2004; 122: 1106-7.

[101] Lascorz J, Burkhardt H, Huffmeier U, et al. Lack of genetic association of the three more common polymorphisms of CARD15 with psoriatic arthritis and psoriasis in a German cohort. Ann Rheum Dis 2005; 64: 951-4.

[102] Peeters M, Vander Cruyssen B, Mielants H, et al. Clinical and genetic factors associated with sacroiliitis in Crohn's disease. $\mathrm{J}$ of Clin Hepathol 2007.

[103] van Tubergen A, Heuft-Dorenbosch L, Schulpen G, et al. Radiographic assessment of sacroiliitis by radiologists and rheumatologists: does training improve quality? Ann Rheum Dis 2003; 62: 519-25.

[104] Bruewer M, Samarin S, Nusrat A. Inflammatory bowel disease and the apical junctional complex. Ann N Y Acad Sci 2006; 1072: 24252

[105] Takeuchi K, Maiden L, Bjarnason I. Genetic aspects of intestinal permeability in inflammatory bowel disease. Novartis Found Symp 2004; 263: 151-8; discussion 9-63, 211-8.

[106] Hollander D, Vadheim CM, Brettholz E, Petersen GM, Delahunty $\mathrm{T}$, Rotter JI. Increased intestinal permeability in patients with Crohn's disease and their relatives. A possible etiologic factor. Ann Intern Med 1986; 105: 883-5.

[107] May GR, Sutherland LR, Meddings JB. Is small intestinal permeability really increased in relatives of patients with Crohn's disease? Gastroenterology 1993; 104: 1627-32.

[108] Marin ML, Greenstein AJ, Geller SA, Gordon RE, Aufses AH, Jr. A freeze fracture study of Crohn's disease of the terminal ileum: changes in epithelial tight junction organization. Am J Gastroenterol 1983; 78: 537-47.

[109] Peeters M, Ghoos Y, Maes B, et al. Increased permeability of macroscopically normal small bowel in Crohn's disease. Dig Dis Sci 1994; 39: 2170-6.

[110] Picco P, Gattorno M, Marchese N, et al. Increased gut permeability in juvenile chronic arthritides. A multivariate analysis of the diagnostic parameters. Clin Exp Rheumatol 2000; 18: 773-8.

[111] Vaile JH, Meddings JB, Yacyshyn BR, Russell AS, Maksymowych WP. Bowel permeability and CD45RO expression on circulating CD20+ B cells in patients with ankylosing spondylitis and their relatives. J Rheumatol 1999; 26: 128-35.

[112] Mielants H, Veys EM, De Vos M, Cuvelier C. Increased intestinal permeability in ankylosing spondylitis. Gut 1992; 33: 1150.

[113] Bjarnason I, Helgason KO, Geirsson AJ, et al. Subclinical intestinal inflammation and sacroiliac changes in relatives of patients with ankylosing spondylitis. Gastroenterology 2003; 125: 1598605 .

[114] Martinez-Gonzalez O, Cantero-Hinojosa J, Paule-Sastre P, GomezMagan JC, Salvatierra-Rios D. Intestinal permeability in patients with ankylosing spondylitis and their healthy relatives. Br J Rheumatol 1994; 33: 644-7.

[115] D'Inca R, Annese V, di Leo V, et al. Increased intestinal permeability and NOD2 variants in familial and sporadic Crohn's disease. Aliment Pharmacol Ther 2006; 23: 1455-61.

[116] Buhner S, Buning C, Genschel J, et al. Genetic basis for increased intestinal permeability in families with Crohn's disease: role of CARD15 3020insC mutation? Gut 2006; 55: 342-7.

[117] Fries W, Renda MC, Lo Presti MA, et al. Intestinal permeability and genetic determinants in patients, first-degree relatives, and controls in a high-incidence area of Crohn's disease in Southern Italy. Am J Gastroenterol 2005; 100: 2730-6.
[118] Rahman P, Inman RD, Gladman DD, et al. Association of IL-23R variants and ankylosing spondylitis (AS). Ann Rheum Dis 2007; 66: 83.

[119] Reveille JD, Zhou X, Bradbury LA, et al. IL-23R is a major determinant of ankylosing spondylitis risk - the TASC study. Ann Rheum Dis 2007; 66: 112 .

[120] Ciccia F, Bombardieri M, Principato A, et al. IL-23 overexpression as immunological signature of subclinical intestinal inflammation in patients with ankylosing spondylitis. Ann Rheum Dis 2007; 66: 83.

[121] Targan SR, Hanauer SB, van Deventer SJ, et al. A short-term study of chimeric monoclonal antibody cA2 to tumor necrosis factor alpha for Crohn's disease. Crohn's Disease cA2 Study Group. N Eng1 J Med 1997; 337: 1029-35.

[122] Westendorp RG, Langermans JA, Huizinga TW, et al. Genetic influence on cytokine production and fatal meningococcal disease. Lancet 1997; 349: 170-3.

[123] Negoro K, Kinouchi Y, Hiwatashi N, et al. Crohn's disease is associated with novel polymorphisms in the 5'-flanking region of the tumor necrosis factor gene. Gastroenterology 1999; 117: 1062-8.

[124] Levine A, Karban A, Eliakim R, et al. A polymorphism in the TNF-alpha promoter gene is associated with pediatric onset and colonic location of Crohn's disease. Am J Gastroenterol 2005; 100 : 407-13.

[125] Linderson Y, Bresso F, Buentke E, Pettersson S, D'Amato M Functional interaction of CARD15/NOD2 and Crohn's diseaseassociated TNFalpha polymorphisms. Int J Colorectal Dis 2005; 20: 305-11

[126] McGarry F, Walker R, Sturrock R, Field M. The -308.1 polymorphism in the promoter region of the tumor necrosis factor gene is associated with ankylosing spondylitis independent of HLA-B27. J Rheumatol 1999; 26: 1110-6.

[127] Fraile A, Nieto A, Beraun Y, Vinasco J, Mataran L, Martin J. Tumor necrosis factor gene polymorphisms in ankylosing spondylitis. Tissue Antigens 1998; 51: 386-90.

[128] Kaijzel EL, Brinkman BM, van Krugten MV, et al. Polymorphism within the tumor necrosis factor alpha (TNF) promoter region in patients with ankylosing spondylitis. Hum Immunol 1999; 60: 1404.

[129] Reich K, Huffmeier U, Konig IR, et al. TNF polymorphisms in psoriasis: association of psoriatic arthritis with the promoter polymorphism TNF*-857 independent of the PSORS1 risk allele. Arthritis Rheum 2007; 56: 2056-64.

[130] Gazouli M, Mantzaris G, Kotsinas A, et al. Association between polymorphisms in the Toll-like receptor 4, CD14, and CARD15/ NOD2 and inflammatory bowel disease in the Greek population. World J Gastroenterol 2005; 11: 681-5.

[131] Braat H, Stokkers P, Hommes T, et al. Consequence of functional Nod 2 and Tlr4 mutations on gene transcription in Crohn's disease patients. J Mol Med 2005; 83: 601-9.

[132] Brand S, Staudinger T, Schnitzler F, et al. The role of Toll-like receptor 4 Asp299Gly and Thr399Ile polymorphisms and CARD15/ NOD2 mutations in the susceptibility and phenotype of Crohn's disease. Inflamm Bowel Dis 2005; 11: 645-52.

[133] Torok HP, Glas J, Tonenchi L, Bruennler G, Folwaczny M, Folwaczny C. Crohn's disease is associated with a toll-like receptor- 9 polymorphism. Gastroenterology 2004; 127: 365-6.

[134] Arnott ID, Nimmo ER, Drummond HE, et al. NOD2/CARD15, TLR4 and CD14 mutations in Scottish and Irish Crohn's disease patients: evidence for genetic heterogeneity within Europe? Genes Immun 2004; 5: 417-25.

[135] Lakatos PL, Lakatos L, Szalay F, et al. Toll-like receptor 4 and NOD2/CARD15 mutations in Hungarian patients with Crohn's disease: phenotype-genotype correlations. World J Gastroenterol 2005; 11: 1489-95.

[136] Arbour NC, Lorenz E, Schutte BC, et al. TLR4 mutations are associated with endotoxin hyporesponsiveness in humans. Nat Genet 2000; 25: 187-91.

[137] von Aulock S, Schroder NW, Gueinzius K, et al. Heterozygous toll-like receptor 4 polymorphism does not influence lipopolysaccharide-induced cytokine release in human whole blood. J Infect Dis 2003; 188: 938-43.

[138] Erridge C, Stewart J, Poxton IR. Monocytes heterozygous for the Asp299Gly and Thr399Ile mutations in the Toll-like receptor 4 gene show no deficit in lipopolysaccharide signalling. J Exp Med 2003; 197: 1787-91 
[139] Snelgrove T, Lim S, Greenwood C, et al. Association of toll-like receptor 4 variants and ankylosing spondylitis: a case-control study. J Rheumatol 2007; 34: 368-70.

[140] Adam R, Sturrock RD, Gracie JA. TLR4 mutations (Asp299Gly and Thr399Ile) are not associated with ankylosing spondylitis. Ann Rheum Dis 2006; 65: 1099-101.

[141] van der Paardt M, Crusius JB, de Koning MH, et al. No evidence for involvement of the Toll-like receptor 4 (TLR4) A896G and CD14-C260T polymorphisms in susceptibility to ankylosing spondylitis. Ann Rheum Dis 2005; 64: 235-8.

[142] Gergely P, Jr., Blazsek A, Weiszhar Z, Pazar B, Poor G. Lack of genetic association of the Toll-like receptor 4 (TLR4) Asp299Gly and Thr399Ile polymorphisms with spondylarthropathies in a Hungarian population. Rheumatology (Oxford) 2006; 45: 1194-6.

[143] FitzGerald O, McInnes I. Spondyloarthropathy: disease at the crossroads of immunity. Best Pract Res Clin Rheumatol 2006; 20: 949-67.

[144] Kontoyiannis D, Pasparakis M, Pizarro TT, Cominelli F, Kollias G. Impaired on/off regulation of TNF biosynthesis in mice lacking
TNF AU-rich elements: implications for joint and gut-associated immunopathologies. Immunity 1999; 10: 387-98.

[145] Hammer RE, Maika SD, Richardson JA, Tang JP, Taurog JD. Spontaneous inflammatory disease in transgenic rats expressing HLA-B27 and human beta $2 \mathrm{~m}$ : an animal model of HLA-B27associated human disorders. Cell 1990; 63: 1099-112.

[146] Taurog JD, Maika SD, Simmons WA, Breban M, Hammer RE. Susceptibility to inflammatory disease in HLA-B27 transgenic rat lines correlates with the level of B27 expression. J Immunol 1993; 150: 4168-78.

[147] Tran TM, Dorris ML, Satumtira N, et al. Additional human beta2microglobulin curbs HLA-B27 misfolding and promotes arthritis and spondylitis without colitis in male HLA-B27-transgenic rats. Arthritis Rheum 2006; 54: 1317-27.

[148] Taurog JD, Richardson JA, Croft JT, et al. The germfree state prevents development of gut and joint inflammatory disease in HLA-B27 transgenic rats. J Exp Med 1994; 180: 2359-64. 